\title{
Front Matter: Volume 6692
}

, "Front Matter: Volume 6692," Proc. SPIE 6692, Cryogenic Optical Systems and Instruments XII, 669201 (26 October 2007); doi: 10.1117/12.773522

SPIE Event: Optical Engineering + Applications, 2007, San Diego, California, United SPIE. States 


\section{PROCEEDINGS OF SPIE}

\section{Cryogenic Optical Systems and Instruments XII}

James B. Heaney

Lawrence G. Burriesci

Editors

26-27 August 2007

San Diego, California, USA

Sponsored and Published by

SPIE

Volume 6692 
The papers included in this volume were part of the technical conference cited on the cover and title page. Papers were selected and subject to review by the editors and conference program committee. Some conference presentations may not be available for publication. The papers published in these proceedings reflect the work and thoughts of the authors and are published herein as submitted. The publisher is not responsible for the validity of the information or for any outcomes resulting from reliance thereon.

Please use the following format to cite material from this book:

Author(s), "Title of Paper," in Cryogenic Optical Systems and Instruments XII, edited by James B. Heaney, Lawrence G. Burriesci, Proceedings of SPIE Vol. 6692 (SPIE, Bellingham, WA, 2007) Article CID Number.

ISSN 0277-786X

ISBN 9780819468406

Published by

SPIE

P.O. Box 10, Bellingham, Washington $98227-0010$ USA

Telephone +1 3606763290 (Pacific Time) · Fax +1 3606471445

SPIE.org

Copyright (c) 2007, Society of Photo-Optical Instrumentation Engineers

Copying of material in this book for internal or personal use, or for the internal or personal use of specific clients, beyond the fair use provisions granted by the U.S. Copyright Law is authorized by SPIE subject to payment of copying fees. The Transactional Reporting Service base fee for this volume is $\$ 18.00$ per article (or portion thereof), which should be paid directly to the Copyright Clearance Center (CCC), 222 Rosewood Drive, Danvers, MA 01923. Payment may also be made electronically through CCC Online at copyright.com. Other copying for republication, resale, advertising or promotion, or any form of systematic or multiple reproduction of any material in this book is prohibited except with permission in writing from the publisher. The CCC fee code is $0277-786 \mathrm{X} / 07 / \$ 18.00$.

Printed in the United States of America.

Publication of record for individual papers is online in the SPIE Digital Library.

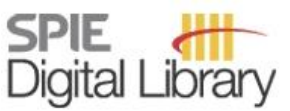

SPIEDigitalLibrary.org

Paper Numbering: Proceedings of SPIE follow an e-First publication model, with papers published first online and then in print and on CD-ROM. Papers are published as they are submitted and meet publication criteria. A unique, consistent, permanent citation identifier (CID) number is assigned to each article at the time of the first publication. Utilization of CIDs allows articles to be fully citable as soon they are published online, and connects the same identifier to all online, print, and electronic versions of the publication. SPIE uses a six-digit CID article numbering system in which:

- The first four digits correspond to the SPIE volume number.

- The last two digits indicate publication order within the volume using a Base 36 numbering system employing both numerals and letters. These two-number sets start with $00,01,02,03,04,05$, 06, 07, 08, 09, OA, OB ... 0Z, followed by 10-1Z, 20-2Z, etc.

The CID number appears on each page of the manuscript. The complete citation is used on the first page, and an abbreviated version on subsequent pages. Numbers in the index correspond to the last two digits of the six-digit CID number. 


\section{Contents}

vii Conference Committee

ix Introduction

\section{CRYOGENIC OPTICAL PROPERTIES AND INSTRUMENT TECHNOLOGY I}

669202 High-fidelity cryothermal test of a subscale large space telescope [6692-01]

M. DiPirro, J. Tuttle, S. Ollendorf, A. Mattern, D. Leisawitz, M. Jackson, J. Francis, T. Hait, NASA Goddard Space Flight Ctr. (USA); P. Cleveland, Energy Solutions International, LLC (USA); D. Muheim, NASA Goddard Space Flight Ctr. (USA); A. J. Mastropietro, Jet Propulsion Lab. (USA)

669204 Temperature-dependent refractive index of $\mathrm{CaF}_{2}$ and Infrasil 301 [6692-03] D. B. Leviton, B. J. Frey, T. J. Madison, NASA Goddard Space Flight Ctr. (USA)

669205 Cryogenic temperature-dependent refractive index measurements of N-BK7, BaLKN3, SF15, and E-SF03 [6692-04]

B. J. Frey, D. B. Leviton, T. J. Madison, NASA Goddard Space Flight Ctr. (USA); Q. Gong, ATK (USA); M. Tecza, Univ. of Oxford (United Kingdom)

669206 Temperature evolution of exciton absorptions in $\mathbf{C d}_{1-\mathbf{x}} \mathbf{Z n}_{\mathbf{x}}$ Te materials [6692-05]

M. A. Quijada, R. Henry, NASA Goddard Space Flight Ctr. (USA)

\section{CRYOGENIC OPTICAL PROPERTIES AND INSTRUMENT TECHNOLOGY II}

669207 Cryogenic system for interferometric measurement of dimensional changes at $40 \mathrm{~K}$ : design and performance [6692-06]

P. Blake, F. Miller, NASA Goddard Space Flight Ctr. (USA); T. Zukowski, Research Support Instruments (USA); E. R. Canavan, NASA Goddard Space Flight Ctr. (USA); A. Crane, ATK (USA); T. Madison, NASA Goddard Space Flight Ctr. (USA); D. Miller, Bastion Technologies, Inc. (USA)

669208 A cryogenic tunable Fabry-Perot interferometer for astronomical observations [6692-07] J. K. Chow, L. A. Ryder, I. Chapman, S. Horner, P. D. Dean, Lockheed Martin Advanced Technology Ctr. (USA)

669209 Design and development of a cryogenic Michelson interferometer [6692-08] P. Lagueux, M. Chamberland, F. Marcotte, A. Villemaire, Telops, Inc. (Canada)

6692 OA The development of a breadboard cryogenic optical delay line for Darwin [6692-09] T. C. van den Dool, F. Kamphues, W. L. M. Gielesen, B. C. Braam, TNO Science and Industry (Netherlands); N. Loix, Micromega-Dynamics (Belgium); P. P. Kooijman, SRON (Netherlands); G. Velsink, Dutch Space (Netherlands); Y. Stockman, CSL (Belgium); J. Benoit, Thales Alenia Space (France); F. Sève, SAGEIS-CSO (France) 
6692 OB Mid-infrared instrumentation for the European Extremely Large Telescope [6692-10] S. Kendrew, B. Brandl, Leiden Observatory, Univ. of Leiden (Netherlands); R. Lenzen, Max Planck Institute for Astronomy (Germany); L. Venema, Astron (Netherlands); H. U. Käufl, G. Finger, ESO (Germany); A. Glasse, UK Astronomy Technology Ctr. (United Kingdom); R. Stuik, Leiden Observatory, Univ. of Leiden (Netherlands)

\section{SPACE CRYOGENIC SYSTEMS I}

6692 OF NIRCam fold mirror and mount designs [6692-16]

A. Nordt, M. Jacoby, B. Biggs, T. Kvamme, T. Cahoon, Lockheed Martin Advanced Technology Ctr. (USA)

$66920 \mathrm{G}$ Cryo-test results of NIRCam optical elements [6692-17]

L. W. Huff, L. A. Ryder, E. T. Kvamme, Lockheed Martin Advanced Technology Ctr. (USA)

\section{SPACE CRYOGENIC SYSTEMS II}

$6692 \mathrm{OH}$ Cryogenic measurements of the dichroic beam splitter for the NIRCam instrument [6692-18] Y. Mao, L. W. Huff, Lockheed Martin Advanced Technology Ctr. (USA); W. Hendricks, C. Kennemore, JDS Uniphase Corp. (USA)

$669201 \quad$ A second generation low stress cryogenic mount for space-borne lithium fluoride optics [6692-19]

E. T. Kvamme, M. Jacoby, Lockheed Martin Advanced Technology Ctr. (USA)

6692 0J NIRCam thermal subsystem [6692-20]

L. Osborne, Lockheed Martin Advanced Technology Ctr. (USA)

\section{SPACE CRYOGENIC SYSTEMS III}

6692 OK JWST-MIRI spectrometer main optics qualification and verification [6692-21] M. Meijers, A. Oudenhuysen, T. Schoenmaker, G. Kroes, ASTRON (Netherlands); R. Jager, NOVA (Netherlands); E. Pauwels, PiE B.V. (Netherlands)

6692 OL MIRI telescope simulator (MTS) folding mirrors [6692-22] J. Serrano, A. G. Moral, E. Pedrosa, J. Moreno, L. Díez, J. Allo, C. Laviada, Lidax (Spain)

$66920 \mathrm{M}$ Overview of the near infrared spectrograph (NIRSpec) instrument on-board the James Webb Space Telescope (JWST) [6692-23]

G. Bagnasco, European Space Agency (Netherlands); M. Kolm, EADS Astrium GmbH (Germany); P. Ferruit, Univ. de Lyon, CNRS (France); K. Honnen, J. Koehler, R. Lemke, M. Maschmann, M. Melf, G. Noyer, EADS Astrium GmbH (Germany); P. Rumler, J.-C. Salvignol, P. Strada, M. Te Plate, European Space Agency (Netherlands)

6692 ON Physical optics model for simulating the optical performance of the NIRSpec [6692-24] M. te Plate, J. L. Alvarez, P.-A. Frugier, European Space Agency (Netherlands); P. Marenaci, EADS Astrium GmbH (Germany) 
6692 OP Photogrammetric metrology for the James Webb Space Telescope integrated science instrument module [6692-26]

M. Nowak, NASA Goddard Space Flight Ctr. (USA); A. Crane, Alliant Techsystems, Inc. (USA); P. Davila, W. Eichhorn, NASA Goddard Space Flight Ctr. (USA); J. Gill, ManTech, Inc. (USA); A. Herrera, Alliant Techsystems, Inc. (USA); M. Hill, J. Hylan, NASA Goddard Space Flight Ctr. (USA); M. Jetten, Northrop Grumman Space Technology (USA); J. Marsh, R. Ohl, NASA Goddard Space Flight Ctr. (USA); R. Quigley, Alliant Techsystems, Inc. (USA); K. Redman, ManTech, Inc. (USA); H. Sampler, G. Wright, NASA Goddard Space Flight Ctr. (USA); P. Young, Young Engineering Services, Inc. (USA)

$66920 Q \quad$ Thermal analysis and seeing improvement of LAMOST enclosure [6692-27]

Z. Chen, H. Shi, Hangzhou Dianzi Univ. (China) and National Astronomical Observatories (China); R. Li, Z. Yao, W. Hao, National Astronomical Observatories (China)

6692 OR Optical alignment of the JWST ISIM to the OTE simulator (OSIM): current concept and design studies [6692-29]

B. J. Frey, P. S. Davila, J. G. Hagopian, J. M. Marsh, R. G. Ohl, M. E. Wilson, NASA Goddard Space Flight Ctr. (USA); P. J. Young, Young Engineering Services (USA)

6692 OS Calculation of the effect of ice on the transmission of the James Webb Space Telescope [6692-30]

J. Arenberg, Northrop Grumman Space Technology (USA)

Author Index 
Downloaded From: https://www.spiedigitallibrary.org/conference-proceedings-of-spie on 25 Apr 2023

Terms of Use: https://www.spiedigitallibrary.org/terms-of-use 


\title{
Conference Committee
}

\author{
Conference Chairs
}

James B. Heaney, Stinger Ghaffarian Technologies, Inc. (USA)

Lawrence G. Burriesci, Lockheed Martin Advanced Technology Center (USA)

Program Committee

David M. Chaney, Ball Aerospace and Technologies Corporation (USA)

E. Todd Kvamme, Lockheed Martin Advanced Technology Center (USA)

Raymond G. Ohl IV, NASA Goddard Space Flight Center (USA)

Leigh A. Ryder, Lockheed Martin Advanced Technology Center (USA)

Mark T. Stier, Goodrich Corporation (USA)

Theodore D. Swanson, NASA Goddard Space Flight Center (USA)

Session Chairs

1 Cryogenic Optical Properties and Instrument Technology I

Raymond G. Ohl IV, NASA Goddard Space Flight Center (USA)

2 Cryogenic Optical Properties and Instrument Technology II

David M. Chaney, Ball Aerospace and Technologies Corporation (USA)

3 Cryogenic Mechanisms and Refrigeration Technology

Theodore D. Swanson, NASA Goddard Space Flight Center (USA)

4 Space Cryogenic Systems I

E. Todd Kvamme, Lockheed Martin Advanced Technology Center (USA)

5 Space Cryogenic Systems II

Mark T. Stier, Goodrich Corporation (USA)

6 Space Cryogenic Systems III

Leigh A. Ryder, Lockheed Martin Advanced Technology Center (USA) 
Downloaded From: https://www.spiedigitallibrary.org/conference-proceedings-of-spie on 25 Apr 2023

Terms of Use: https://www.spiedigitallibrary.org/terms-of-use 


\section{Introduction}

This volume contains the proceedings of our $12^{\text {th }}$ Cryogenic Optical Systems and Instrumentation Conference that was held in San Diego, 26-30 August 2007. Previous books in this series include SPIE volumes 509 (1984), 619 (1986), 973 (1988), 1340 (1990), 1765 (1992), 2227 (1994), 2814 (1996), 3435 (1998), 4131* (2000), 4822 (2002), 5172 (2003), and 5904 (2005). Taken together, these yellow-covered proceedings are a veritable library documenting more than two decades of technological advances related to the design, development, testing and performance of optical components and instruments and the mechanisms and techniques used to cool and maintain them at cryogenic temperatures. The international community is well represented in their contents.

From the beginning, the needs of the aerospace community have had a formative influence on the evolution of this technology. Space satellite missions such as UARS, COBE, SIRTF (Spitzer), Cassini, WMAP, et al. have contained instrumentation that was required to operate at temperatures near absolute zero. Their design, testing, and performance evaluation challenged their cryogenic engineering and forced an advancement of the state-of-the-art. In our most recent conferences in 2005 and 2007, NASA's JWST mission, with its joint NASA/ESA instrumentation suite, has contributed significantly to the contents of Vol. 5904 and this current volume. A statement of the challenges confronted and the clever engineering remedies applied can be found in the papers contained in these proceedings.

We now know that the average temperature of the universe is closer to absolute zero than the anomalously hot portion of that universe that we inhabit. The exploitation of cryogenic technology enables us to travel from our world into the universe beyond, extracting knowledge of our own origins as we go. If we take a step back from the intricately complex details of the cryogenic technology discussed in these pages and view its workings from a more distant and philosophical perspective, we can understand cryogenic optical systems and instruments as an enabling technology that underpins our ability to explore the universe around us and to find our place within it. It is a worthwhile way to spend one's time.

Lawrence G. Burriesci James B. Heaney

*Joint with Infrared Spaceborne Remote Sensing VIII 
Downloaded From: https://www.spiedigitallibrary.org/conference-proceedings-of-spie on 25 Apr 2023

Terms of Use: https://www.spiedigitallibrary.org/terms-of-use 